\title{
Amerika, de Franz Kafka: de pai para filho
}

Davi Andrade Pimentel ${ }^{a}$

\section{Resumo}

Este artigo analisa, no romance $\mathrm{O}$ desaparecido ou Amerika, de Franz Kafka, a configuração da lei paterna enquanto sistema opressor que julga e sentencia o filho segundo uma lei-conceito predefinida, que acaba por tornar esse julgamento uma ficção. Dois territórios democráticos, um utópico e outro real, apresentam-se como o cenário do julgamento, da sentença e do castigo do filho. Diante da lei do pai, o filho não dispõe de nenhuma possibilidade de escolha, pois se encontra enredado em um pecado original que, antes de sua própria existência, já o tinha sentenciado como culpado. No desenvolvimento deste artigo, três narrativas curtas de Kafka são apresentadas como exercício de reflexão sobre essa lei paterna autocrática, são elas: A metamorfose, $\mathrm{O}$ veredicto e Carta ao pai. Textos de Jacques Derrida, "Préjugés: devant la loi", e de Jacques Rancière, "O continente democrático", dão a este artigo uma estrutura teórica pela qual a lei paterna kafkiana pode ser pensada.

Palavras-chave: Franz Kafka, Jacques Derrida, Jacques Rancière, lei paterna, democracia. 
John também riu, mas por outro motivo - riu de pura alegria.

- "Oh, admirável mundo novo!" - repetiu. - "Oh, admirável mundo novo, que encerra criaturas tais!"... Partamos em seguida.

Aldous Huxley. Admirável mundo novo.

\begin{abstract}
1 Fazer rizoma é fazer com que o pensamento se desvie de um padrão arbóreo, de cuja unidade central - de cujo pensamento dado como mais verdadeiro - nasceriam as demais raízes, ou melhor, os demais pensamentos, sujeitados a uma proposição ou afirmação já predefinida. Segundo Deleuze e Guattari, fazer rizoma é dialogar, é expandir o pensamento para além das linhas de limitação de um centro de verdade absoluta, até mesmo por não termos verdades, mas possibilidades de verdades, todas elas passíveis de serem aceitas e negadas e deformadas e desterritorializadas e reterritorializadas: “Um rizoma não começa nem conclui, ele se encontra sempre no meio, entre as coisas, inter-ser, intermezzo. A árvore é filiação, mas o rizoma é aliança, unicamente aliança. A árvore impõe o verbo 'ser', mas o rizoma tem como tecido a conjunção 'e... e... e...'” (DELEUZE; GUATTARI, 2011, p. 48).

2 Nesteartigo, mantémse a grafia de certas palavras que surgem no original alemão e que, por sugestão da tradutora Susana Kampff Lages, devem permanecer na tradução para o português, uma vez que fazem parte de todo um constructo de seu autor, como, por exemplo: "Hotel occidental" e "Theatro de Oklahama". O título Amerika foi acrescentado por seu amigo e executor testamentário Max Brod. Kafka, em vida, tinha intitulado o seu romance de $O$ desaparecido.
\end{abstract}

\section{Prólogo}

Do navio abarrotado de estrangeiros, Karl Rossmann, cujo destino fora imposto por seu pai, avista, já na entrada do porto de Nova York, o esplendor da "estátua da deusa da liberdade, que há muito vinha observando, como que banhada por uma luz de sol que subitamente tivesse se tornado mais intensa. $\mathrm{O}$ braço com a espada erguia-se como se tivesse recém se elevado" (KAFKA, 2012, p. 13). A imagem da estátua kafkiana, que por segundos nos remete à imagem da Estátua da Liberdade, uma vez que estamos em Nova York e, consequentemente, na América, rompe com um vínculo imediato que possamos estabelecer com a estátua nova-iorquina. Nesse momento, o narrador kafkiano opera uma desterritorialização nos moldes deleuzianos ao fazer rizoma ${ }^{1}$ com duas imagens criando uma terceira: a estátua, que surge no parágrafo de abertura de O desaparecido ou Amerika ${ }^{2}$, captura os códigos semânticosespaciais da Estátua da Liberdade, não por acaso ela se encontra próxima ao porto de Nova York, e os códigos semânticosverbais da imagem da deusa grega Atena, a espada e a sua forte inclinação para a justiça serão elementos agregadores ao longo da narrativa kafkiana. Da captura dos códigos, Kafka faz surgir uma terceira estátua, a da "deusa da liberdade", que tanto seria o devir-Estátua da Liberdade da deusa Atena quanto o devir-deusa Atena da Estátua da Liberdade, "os dois devires se encadeando e se revezando segundo uma circulação de intensidades que empurra a desterritorialização cada vez mais longe" (DELEUZE; GUATTARI, 2011, p. 26).

A imagem da deusa banhada por intensa luminosidade não é um mero ornamento na narrativa de Kafka, ela figura, antes, como sendo a própria narrativa apresentada pelo escritor tcheco. Ela é a porta de abertura da epopeia da busca por justiça de Karl Rossmann: para se dar justiça e para fazer justiça, por isso a espada-justa mitológica é tão importante no decorrer do texto de $O$ desaparecido; bem como é a porta que 
fecha, ela é a América que decreta o seu fracasso, ela o julga como não merecedor da justiça. Mas qual seria a justiça que Karl almejava e qual é a justiça que o julga? Há apenas uma justiça ou múltiplas justiças? Existiria $a$ justiça? Inicialmente Karl vislumbra a América a partir de uma concepção utópica de democracia: um mundo novo, justo, homogêneo, onde os indivíduos seriam semelhantes entre si, teriam as mesmas oportunidades, os mesmos direitos e a mesma voz. Karl segue, de início, uma perspectiva tocquevilliana da democracia americana, nos moldes como ela é apresentada por Jacques Rancière em "O continente democrático": "Qual é, efetivamente, o objeto da metáfora tocquevilliana? É apresentar o espaço simbólico americano como espaço da visibilidade integral e da semelhança infinita. [...] A igualdade é uma estrutura do visível: a igual visibilidade do semelhante" (RANCIÈRE, 2017 , p. 228-9). Uma perspectiva da visibilidade mimética homogênea que exclui, claro, a própria ideia de democracia, uma vez que o estado democrático americano, como muitos outros estados, não executa de forma exemplar - e, sobre essa questão, a reflexão kafkiana, em $O$ desaparecido, é bastante pertinente - a própria ideia de democracia, o seu real sentido. A vontade de ver e de ser visto, de ter e de ter o desejo de ter, impede, ao mesmo tempo que constrói, o ideal de democracia no qual estamos inseridos: "Por uma reversão dialética, aquela 'separação dos poderes', que era a limitação maléfica do agir político, torna-se a limitação benéfica da inércia democrática" (RANCIÈRE, 2017, p. 234).

Se não temos de fato uma realização ideal da boa democracia tocquevilliana, não teremos, portanto, de fato uma realização ideal da justiça. Em quase nada o velho mundo europeu de partida se diferencia do novo mundo americano de chegada, porém, essa constatação somente ganhará escopo nas reflexões de Karl quando os obstáculos começarem por invadir o seu caminho rumo à realização de se fazer justiça através de um emprego justo na terra democrática americana. O primeiro obstáculo de Karl é a hospitalidade: "Ele deve pedir a hospitalidade a uma língua que por definição não é a sua, aquela que lhe impõe o chefe da casa, o anfitrião, o rei, o

Todas as traduções dos textos em francês citados neste artigo são de minha autoria. senhor, o poder, a nação, o Estado, o pai, etc" (DERRIDA, 1997, p. 21)3. Assim que chega a Nova York, Karl diz ao foguista: "Praticamente não sei nada de inglês. Creio que em geral aqui 
as pessoas têm tanta prevenção contra estrangeiros!" (KAFKA, 2012, p. 17). A América o vê como estrangeiro, impõe-lhe limites, embora ela própria tenha ganhado a independência por meio de mãos estrangeiras, sendo ela própria um terrenode-estrangeiros. Daí podemos tirar uma característica principal da América, a sua ambiguidade: "A América [...] é o território de um visível sempre problemático [...] um segredo por trás de cada porta e cada corpo: um alienado escondido em cada diretor de asilo, um culpado em cada inocente [...] uma inverossimilhança em cada verdade" (RANCIÈRE, 2017, p. 229).

Essa ambiguidade em relação ao estrangeiro atravessa também a perspectiva de Kafka, para quem o estrangeiro não é um indivíduo que possa ser acolhido ou que possa ter razão: "Para ele, aquele que sobre-vem [dazu-kommt] nunca tem razão, pois, num certo sentido, Kafka vê o problema do estranho, do recém-chegado, do judeu, com os olhos daquele que não acolhe o estrangeiro" (ANDERS, 2007, p. 36-7). Kafka, um homem tcheco, que escrevia em alemão e que era judeu, mas que não se via como tcheco, nem estava tão confortável na língua alemã e que questionava certos aspectos da religião e da lei judaicas. Ou seja, um homem singularmente estrangeiro em seu próprio corpo, língua e espiritualidade: "Sua visão do mundo é, até certo ponto, contaminada por esta múltipla condição de nãopertencer: ora fica no primeiro plano de sua concepção do mundo este grupo substancial, do qual não participa, ora aquele - ainda que, em geral, 'mundo' signifique o todo daquilo em que ele não está, ou seja, o mundo do poder" (ANDERS, 2007, p. 27). Kafka não se solidariza com o estrangeiro por acreditar que não pode existir solidariedade entre seres estranhos, sendo ele próprio um exemplo de sua argumentação. Talvez seja essa perspectiva negativa que dê aos seus personagens, sempre estrangeiros, em múltiplos aspectos, o tom de indivíduos sempre destinados ao fracasso: “E, ao recordar-se disso, Karl disse consigo mesmo que ele também tinha sofrido bastante como ascensorista e que, afinal, tudo tinha sido em vão, pois esse serviço agora não se revelara, como ele havia esperado, um primeiro passo na direção de uma colocação melhor; pelo contrário, agora ele havia decaído ainda mais, tendo chegado até perto de ser preso" (KAFKA, 2012, p. 172). 


\section{A Lei do Pai}

A viagem de Karl à América é a sentença proferida por seu pai ao acreditar que o filho burlou a lei por ter engravidado Johanna Brummer, a empregada da família Rossmann. Sabemos desse fato por seu tio, Edward Jakob, que o reconhece no navio, já atracado no porto de Nova York, no momento em que Karl busca fazer justiça à pessoa do foguista, que se diz injustiçado pelo maquinista-chefe. Um ato de justiça que fracassa, como fracassará tantos outros atos do personagem; porém, diferentemente de outras narrativas de Kafka, cada fracasso fará par com uma ideia de esperança futura: "Nenhum dos golpes que ferem a Rossmann tem a fatalidade do definitivo. Entre os livros de Kafka, é este o mais esperançoso e o menos consternador" (CANETTI, 1988, p. 88). Karl a todo momento cai e se levanta; e assim, nesse movimento circular narrativo, o texto se desenvolve, em um ritmo que podemos definir como repetitivo e, contudo, nunca o mesmo - os elementos mudam, nunca a ação circular que tem Karl como centro: "O caráter cíclico, a circularidade da obra de arte que não avança nunca, não é, certamente, uma falha artística" (ANDERS, 2007, p. 47). Karl foi julgado e sentenciado por seu pai, mas a partir de qual lei? Derrida, em "Préjugés: devant la loi", texto que se encontra na coletânea La faculté de juger organizada por Lyotard, reflete que, antes de realizarmos um julgamento, deveríamos nos perguntar como julgar? e não o que julgar?, como se já de antemão conhecêssemos a lei: "Começar pela questão como? e não pela questão o que?, isso pode voltar a suspender a prerrogativa clássica do julgamento" (DERRIDA, 1985, p. 93).

Através de seu tio, sabemos a sua história: Karl, sem nenhum interesse prévio por Johanna, é levado por ela ao seu pequeno quarto de empregada e lá é abraçado, agarrado e despido, sendo, posteriormente, violado. É essa a palavra, Karl, aos dezessete anos, fora violado por uma mulher mais velha: "ela então empurrou algumas vezes sua barriga contra ele - ele teve a sensação de que ela fosse parte de si mesmo, e talvez por esse motivo foi tomado por uma terrível sensação de desamparo. Chorando, ele chegou finalmente até sua própria cama" (KAFKA, 2012, p. 35). Se por acaso pensássemos em um possível julgamento justo, os papéis de vítima e de culpado se inverteriam. Mas em nenhum momento o pai de Karl o 
interpela ou busca as razões que o levaram a se envolver com a empregada. O pai Rossmann parte, na verdade, de um prejulgamento ou, se preferirmos, de um preconceito, de uma ideia já enraizada em boa parte das comunidades burguesas, que seria a seguinte: se uma empregada engravida em uma casa de família é porque o patrão a violou, se deitou com ela, se utilizou de seu poder para subjugá-la, restando-lhe, claro, assumir a sua responsabilidade. $O$ pai enquadra o filho em uma lei já previamente formulada, em uma lei-conceito, em uma lei predefinida, que já existia bem antes de seu nascimento:

Ele [Lyotard] nos lembra sem cessar de um julgamento que, por não estar fundado, por não ser então nem o primeiro nem o último, não está por isso menos em curso, falando em nós antes de nós, permanente como um tribunal que manteria sessão sem descontinuar, e cuja sessão que não se interrompe teria lugar mesmo quando ninguém está lá. (DERRIDA, 1985, p. 97-8).

Nessa perspectiva da lei predefinida, todo e qualquer julgamento é uma ficção, pois, justamente, não se julga a ação presente, como a violação de Karl e todas as suas prerrogativas, mas se julga uma ação passada, ação-conceito, que serviria de modelo para toda e qualquer ação que se assemelhasse à açãomodelo, e a sentença, consequentemente, seria a mesma sentença estipulada no passado: ou a expulsão da empregada ou o afastamento do familiar que cometeu o delito, por exemplo. É por isso que a questão levantada por Derrida se torna tão pertinente: "Julga-se sem critério" (DERRIDA, 1985, p. 94). Devemos, antes de mais nada, perguntar-nos como julgar? Com essa questão, em que não temos os meios verdadeiros, incorruptíveis, para julgar o outro, para definir o que seria crime, delito, direito, verdade, mentira, democracia, a lei se apresenta também como ficção. Não existe $a$ lei, porque não existe $a$ verdade; o que realmente existe é uma ficção para que uma possível ordem se estabeleça, não por menos o que chamamos de crimes nunca deixaram de existir. O que entendo por delito não é necessariamente o que o outro entende por delito: “a questão 'Como julgar?' dá também a entender a impotência, a angústia, o pavor ou o recuo de quem se recusa diante do que não pode ser decidido ou do double bind: então como julgar quando não se pode ou não se deve ou não se tem 
nem os meios nem o direito para isso?" (DERRIDA, 1985, p. 94). O julgamento, então, se torna matéria complexa.

Apesar de ter tido um julgamento fictício, não democrático, no sentido ideal da palavra, uma vez que a democracia também é uma ficção, e não ato de deliberada justiça, pois os homens não são iguais perante a lei, e sim testemunhas de uma lei democrática que sobrevive a partir de utopias que acabam por criar, ficticiamente, uma ideia/conceito de sociedade e de comunidade, Karl, ainda assim, busca na América fazer-se justiça aos olhos do pai, como se a América fosse o reduto de uma democracia honesta que lhe pudesse oferecer os instrumentos necessários para alcançar o seu objetivo: "Se seus pais pudessem vê-lo agora: lutando pelo bem, em terra estrangeira [...] Será que iriam rever a opinião que tinham a seu respeito? [...] Iriam finalmente olhá-lo nos olhos, naqueles olhos que lhes prestavam tanta devoção?" (KAFKA, 2012, p. 29-30). Porém, Karl esquece, ou não percebe com clareza, que nada distingue a utópica boa democracia americana da má democracia europeia. A lei democrática não permite horizontes de homogeneidade. A democracia é constituída a partir de lutas entre poderes que estão sempre por subjugar e libertar/libertar e subjugar os indivíduos que fazem parte de uma sociedade, seja ela americana ou europeia: "O lugar da democracia é o da visibilidade provisória e ambígua, da verdade inverossímil. A democracia é a configuração de todos esses jogos do múltiplo que se faz e se desfaz nas relações instáveis do ver e do não ver, do ser visto e do ser invisível, nas relações complexas do visível e do dizível" (RANCIÈRE, 2017, p. 238-9).

Em seu movimento utópico, ou alienado, no qual o maquinário democrático americano lhe é totalmente estranho, Karl supõe ser possível anular um ato velho, o julgamento do pai, por meio de um ato de justiça novo, a democracia americana, não compreendendo que ambos fazem parte de um sistema bem mais antigo, que ambos estão filiados a um único sistema de ideias: “O pai é quem pune, mas é ao mesmo tempo quem acusa. $O$ pecado do qual ele acusa o filho parece ser uma espécie de pecado original (Erbsünde)" (BENJAMIN, 2012, p. 150). Benjamin, em "Franz Kafka: a propósito do décimo aniversário de sua morte", ao sugerir que a sentença lançada ao filho seria uma sentença que a ele já estaria predestinada como sendo uma espécie de pecado original, como se todos os herdeiros 
de Kafka fracassassem por serem indivíduos que nasceram do fracasso, submetidos a uma lei anterior, velha e atual; nesse momento, Benjamin dialoga fortemente com Derrida, no que corresponde a compreender a lei, o julgamento, enquanto ficção, e com Rancière, no que corresponde a compreender o sistema ideal democrático ou a boa democracia como verdade inverossímil. Seria como se Karl já pertencesse a uma espécie de julgamento, lembrando Lyotard, antes mesmo de ter nascido e já viesse marcado pelo pecado original, sem a liberdade de poder escolher o curso de sua vida, uma vez que seu destino já estaria traçado por uma lei-conceito que estipula que em toda e qualquer casa de família, quando se tem um patrão e uma empregada, haverá a possibilidade de ser cometido um delito sexual, podendo ele, dessa forma, ter como consequência um herdeiro indesejado. Esse pecado original, com suas diferentes nuances, percorrerá toda a obra kafkiana, o que implica dizer que seus personagens já trazem no corpo a marca do delito, por isso fracassam sempre, pois já são culpados e aos culpados nada resta, a não ser o sentimento de culpa: “O problema é que o mundo não tem boa vontade para aquele que o atravessa - $\mathrm{e}$ que é sempre um acusado potencial" (CALASSO, 2006, p. 169).

O mundo democrático, na verdade, não é democrático e Kafka sabe disso como nenhum outro escritor. Na obra kafkiana, a figura do pai é a figura do poder autocrático. E o poder, seja ele qual for, esteja ele na figura de um alto funcionário ou de uma autoridade qualquer nos textos kafkianos, é a prefiguração da imagem paterna que pune, como podemos ler em um trecho da Carta ao pai: "Meus escritos tratavam de você [do pai], neles eu expunha as queixas que não podia fazer no seu peito" (KAFKA, 1997, p. 52). Os seus personagens, apesar de já trazerem a marca do pecado original, lutam contra esse poder que imputa a sentença que os define como culpados. $O$ desaparecido, como $O$ castelo e $O$ processo, é uma narrativa que busca reverter o pecado original, a sentença proferida pelo pai-poder. A busca por justiça, a busca por entrar no castelo e a busca por saber a verdade do seu processo são todas tentativas, fracassadas, de reverter a culpabilidade imposta por um julgamento anterior à existência desses personagens. E, ao mesmo tempo, são tentativas de incorporação ao poder-paterno, de reestabelecer os laços de uma unidade que há tempos se encontra perdida e impossível de ser reestabelecida: "A situação 
dos 'heróis' [de Kafka] é a de exilados, de filhos pródigos que desesperadamente procuram voltar ao 'lar paterno' de que partiram num ato de emancipação e de rebeldia, isto é, que procuram entrar na 'lei', numa ordem significativa, coerente e humana - debalde, porém, porque a própria ordem se tornou absurda e irracional" (ROSENFELD, 2015, p. 259).

A situação dos "heróis" de Kafka diante de seus paispoderes pode ser definida da seguinte maneira: eu menor que mеи pai, eи maior que meи pai е eи igual aо mеи pai.

\section{1. еи тепоr que теи pai}

A maioria dos escritos kafkianos faz parte do eu menor que meu pai, como, por exemplo, os três romances citados no parágrafo anterior. Nas narrativas curtas em que a figura do pai está realmente presente, destacam-se $O$ veredicto e $A$ metamorfose, textos em que o movimento democrático familiar é totalmente nulificado. O filho não tem voz, está sob o jugo de um pai autoritário e cerceador. Em A metamorfose, numa certa manhã, Gregor Samsa acorda metamorfoseado em inseto, anulando, dessa maneira, a sua utilidade no seio familiar, uma vez que, não podendo trabalhar, perde a função que lhe foi imposta direta e indiretamente por seu pai: a de provedor dos Samsas. Gregor, ao metamorfosear-se em inseto, torna-se um parasita de sua família parasita, invertendo assim os papéis antes preestabelecidos por seu pai: "Se essa conjectura for pertinente, o que então se percebe é mais uma vez a vigência do princípio de inversão em que Kafka é um mestre; pois se antes a família vivia parasitariamente às custas do trabalho de Gregor e da sua alienação no mundo dos negócios [...], ele agora é, aos olhos da família 'deserdada' pela sua metamorfose, apenas um inseto parasita" (CARONE, 2009, p. 23).

A metamorfose de Gregor pode ser compreendida como o momento em que o indivíduo não compactua mais com o sistema alienatório disposto pelo mundo do trabalho do qual (sobre)vive. Um sistema que faz do homem uma peça e um produto da máquina capitalista: “De fato, o homem criou, por assim dizer, uma nova natureza e esse produto do homem, que é a técnica e a ciência, por sua vez reproduz o homem à sua maneira. $\mathrm{O}$ homem torna-se, por assim dizer, produto 
do seu próprio produto, é modificado pelos seus produtos" (ROSENFELD, 1994, p. 43). Por não compactuar com o sistema capitalista - e por que não, democrático, e, aqui, temos mais uma vez a ironia kafkiana - Gregor acorda metamorfoseado em inseto, em uma peça avariada que precisa ser jogada fora, pois perdeu a sua utilidade no todo maquinário. Esse deslocamento grotesco executado por Kafka em sua ficção revela o grotesco que é a nossa própria realidade: "Kafka revela, através da sua técnica de estranhamento, o estranhamento encoberto da vida cotidiana - e desse modo é outra vez realista. Seu 'desfiguramento' fixa" (ANDERS, 2007, p. 18). O homem para (sobre)viver no mundo dito democrático precisa se tornar peça de máquina, ser homem-profissão, ou então acaba por morrer metamorfoseado em inseto.

O pai manipulador, temendo ter que assumir novamente o papel de provedor da família, começa a trabalhar a substituição do filho-inseto pela filha que acabara de florescer. Entretanto, algo dificulta o seu trabalho: Gregor. O filho, estando desobrigado de sua função, não procurou em nenhum momento sair do sistema familiar, o que de certo modo impedia qualquer avanço do pai na concretização de seu projetoparasita, pois o filho se tornara um inútil que poderia macular a imagem da família e, sobretudo, a imagem de sua irmã no mundo do trabalho. Enquanto permanecesse na obscuridade de seu quarto, Gregor poderia contornar as investidas de seu pai, que procurava, por vezes, acertá-lo com qualquer objeto que tivesse em suas mãos. Todavia, quando o desejo pelo exterior passa a ser maior do que o desejo de sobrevivência, Gregor acaba por selar a sua própria morte, uma vez que o mundo exterior, o mundo pertencente aos seus familiares, não admite o indivíduo que não pode exercer uma função, um trabalho. Então, o pai, o senhor da casa, precisa matar o filho em nome da própria sobrevivência de sua família. Gregor não tem voz para se defender, apenas grunhidos que se confundem com o seu todo inútil: "A maçã apodrecida nas suas costas e a região inflamada em volta, inteiramente cobertas por uma poeira mole, quase não o incomodavam. [...] Depois, sem intervenção da sua vontade, a cabeça afundou completamente e das suas ventas fluiu fraco o último fôlego" (KAFKA, 1997a, p. 78). A maçã que o golpeia é a marca de seu pecado original, a marca de seu destino prejulgado de antemão: "No mundo primitivo, 
as leis e normas prescritas permanecem não escritas. O homem pode transgredi-las sem o saber, incorrendo assim em pecado. Contudo, [...] não é acaso, mas destino, o qual se apresenta aqui em toda a sua ambiguidade" (BENJAMIN, 2012, p. 150).

$\mathrm{Na}$ narrativa de $\mathrm{O}$ veredicto, temos dois territórios: um solar, onde se encontra o filho, e um sombrio, onde reina o pai. No primeiro deles, temos Georg, o filho, que escreve uma carta a um amigo que se refugiou na Rússia, mais precisamente em São Petersburgo. Segundo nos relata, por ter-se saído melhor tanto profissional quanto amorosamente, é maior que o amigo e maior também que o pai, pois, em sua administração, a firma da família cresceu de modo surpreendente, quintuplicou-se o movimento e dobrou-se o número de funcionários. Nesse território, o filho deixa entrever que a relação com o pai é uma relação das mais comuns, em que ambos sabem os seus direitos e deveres. Entretanto, quando Georg deixa o seu território e ultrapassa o limiar do quarto do pai, uma perspectiva mais sombria invade a narrativa: "Surpreendeu Georg como estava escuro o quarto do pai mesmo nessa manhã ensolarada" (KAFKA, 1998, p. 15). Luz e escuridão são opostos, e um sempre pode dominar o outro. Ao lado do pai, as certezas proferidas pelo filho caem por terra, o que antes dissera perde toda a validade no território do pai. Este age com um poder tamanho que diminui, humilha e descentra o filho: "- Vocênão tem nenhum amigo em São Petersburgo. Você sempre foi um trapaceiro e não se conteve nem mesmo diante de mim. Como iria ter justamente lá um amigo? Não posso de maneira alguma acreditar nisso" (KAFKA, 1998, p. 18). A suposta superioridade do filho é massacrada pela lei do pai, que se apresenta tanto maior fisicamente do que o filho: "'Meu pai continua sendo um gigante'" (KAFKA, 1998, p. 15); quanto maior energicamente: "E mesmo que seja a última força que tenho, ela é suficiente para você, demais para você" (KAFKA, 1998, p. 20).

Georg sempre foi um trapaceiro, segundo a lei paterna. E por ter sido sempre enganador, dissimulado, insensível, o veredicto de seu pai é a sua morte por afogamento: "Por isso saiba agora: eu o condeno à morte por afogamento!" (KAFKA, 1998 , p. 24). Os recursos do filho frente ao tribunal concebido por seu pai são todos negados. Georg não tem direito, no território autocrático de seu pai, à defesa, pois seu destino já fora traçado, já se encontrara preestabelecido. E a lei que 
o julga não o julga no momento presente de sua ação, mas o julga a partir de uma ação passada, da qual ele não teve nenhuma participação, por isso o seu julgamento é uma ficção, pois a lei remonta a uma ação primitiva da qual ele próprio se tornou vítima sem o saber: "Mas quem é acusado desse pecado original, hereditário - o pecado de haver engendrado um herdeiro (Erbe) - senão o pai, pelo filho? Assim, o pecador seria o filho" (BENJAMIN, 2012, p. 150). Pecador sem pecado, injustiçado por uma lei justa primitiva, vencedor que perde o direito à vida, Georg se lança da ponte com uma ideia, talvez ingênua, de reestabelecer com o pai uma união, desde sempre já confiscada através da aceitação da lei paterna primitiva: “Queridos pais, eu sempre os amei - e se deixou cair" (KAFKA, 1998, p. 25). Porém, o estar-vivo do pai e o estar-morto do filho impossibilitam qualquer re-união familiar.

Entre Georg e Gregor existe uma comunicabilidade que vai além da semelhança de seus nomes: ambos foram julgados e condenados pela lei paterna a partir de uma lei primitiva que se centra no pecado original, que faz de seus herdeiros indivíduos destinados ao fracasso, ou à morte. Num primeiro plano de interpretação textual, o que se poderia configurar como o monstruoso das relações entre pai e filho, o monstruoso sendo a imagem do filho morto pelo próprio pai, é, na verdade, apenas um pano de fundo para um monstruoso ainda mais incisivo: a linguagem de protocolo de Kafka. Adorno, em "Anotações sobre Kafka", resume de forma precisa o monstruoso kafkiano: "Não é o monstruoso que choca, mas sua naturalidade" (ADORNO, 1998, p. 243). Mais rigoroso do que Deus em relação a Abraão, Kafka deixa o pai executar o próprio filho e narra, da forma mais corriqueira possível, o cutelo atravessando o pescoço do filho-cordeiro, não sendo o pai interrompido em nenhum momento por um anjo salvador. Kafka, a partir desse instante, se torna maior do que Deus.

A linguagem de protocolo de Kafka se estrutura a partir da nulidade do metafórico e do simbólico: "Kafka mata deliberadamente toda metáfora, todo simbolismo, toda significação, não menos que toda designação" (DELEUZE; GUATTARI, 2015, p. 45). A escrita kafkiana preza a objetividade de suas narrativas, o uso da palavra em toda a sua clareza, sem artifícios, sem véus, sem carcaças significativas que pudessem encobrir o seu corpo nu, por isso a fidelidade à palavra kafkiana 
é tão importante, pois é a partir dela que o enigma-Kafka pode ser solucionado: "Somente a fidelidade à letra pode ajudar, e não a compreensão orientada" (ADORNO, 1998, p. 242). A linguagem protocolar kafkiana provém, decerto, da linguagem do direito que Kafka manuseou tão bem enquanto trabalhava nas companhias de seguro. Uma linguagem crua e, ao mesmo tempo, comum, desprovida de sutilezas, de acessórios, que pudessem maquiá-la. Todavia, tratando-se de Kafka, essa linguagem comum é, por sua vez, desterritorializada. A palavra kafkiana, a partir do limite imposto por sua significação comum, diz algo mais do que poderia dizer caso estivesse em um ambiente não-ficcional. Kafka faz da palavra do mundo uma palavra poética sem confiscar a sua origem. Desse modo, a linguagem do mundo e a linguagem de Kafka são e não são a mesma linguagem: "E é este o procedimento constante de Kafka: por trás das fórmulas da linguagem comum abre-se inesperadamente esse espaço em que as palavras reverberam e geram significados, adquirindo uma intensidade por vezes paralisante" (CALASSO, 2006, p. 28).

A partir do uso que faz da linguagem protocolar, Kafka naturaliza as imagens estranhas, cruéis, limítrofes e aterrorizantes que entrecruzam o seu espaço ficcional, como a morte do filho executada pelo pai: "Kafka, portanto, apresenta o hediondo de uma maneira desumana por ser desumano, e isto parece-me ser a maneira mais honesta de focalizar o desumano" (ROSENFELD, 1994, p. 59). Maquiar, atenuar, abrandar e moderar não são os tons permitidos por uma linguagem que se constrói não-metafórica. Uma linguagem que exige do seu leitor não um estado de contemplação, mas de proximidade. Através dos choques impostos pela linguagem protocolar kafkiana, o leitor é chamado a participar de seu mundo cru, em que os seus personagens estão constantemente ameaçados por uma lei presente-ausente que os subjuga e que nunca de fato se apresenta. Uma lei que se mantém presente por meio de sua ausência: "a lei em pessoa, se podemos dizer isso, nunca está presente, embora 'diante da lei' pareça significar 'em presença da lei'” (DERRIDA, 1985, p. 119). Kafka, em suas narrativas, executa um processo de esgarçamento da própria lei, esvaziando-a, tornando-a sem objetivo, ou melhor, sem objeto, tornando-a ilógica e, geralmente, sem propósito, o que leva muitos de seus leitores a classificar a 
lei kafkiana de absurda. Porém, acredito, a lei kafkiana em nenhum momento é absurda, na verdade, ela é uma lei que opera a partir de sua total nulidade; uma lei que, apesar de sua patente representatividade, julga e sentencia, embora não tenha os meios idôneos, o direito e a razão necessários para julgar e sentenciar. A lei de Kafka tem apenas casca, não conteúdo. Os textos kafkianos "pressentem a lei como pura forma vazia e sem conteúdo, cujo objeto permanece irreconhecível: a lei não pode, portanto, enunciar-se a não ser em uma sentença, e a sentença não pode se apreender senão em um castigo" (DELEUZE; GUATTARI, 2015, p. 81).

Em Kafka, "o que julgar?" não se dirige para nada definido, e "como julgar?" se perde na imprecisão dos meios. É por esse motivo que Karl, de $O$ desaparecido, permanece ao longo da narrativa sob o olhar sem vida do pai: “Tanto maior foi a atenção com que escrutinou aquela fotografia que tinha diante dos olhos, tentando captar o olhar do pai dos mais diferentes ângulos. Mas, por mais que modificasse sua visão alterando a posição da vela, o pai permanecia sem vida: seus bigodes retos e densos não correspondiam em nada à realidade, não era um bom retrato" (KAFKA, 2012, p. 93). A lei do pai não é de livre alcance para o filho Karl. Ela permanecerá sem vida, tornada segredo: "Ninguém conhece o interior da lei" (DELEUZE; GUATTARI, 2015, p. 81). Por ser uma lei própria, por pertencer a uma lei-conceito de existência anterior à existência de Karl, leiconceito que, por sua vez, incorpora muitas outras leis próprias, particulares, a lei do pai nunca poderá ser a mesma lei do filho, por isso o fracasso sistemático de Karl na sua busca por justiça, pois a sua justiça não é a mesma justiça do pai: restará a ele permanecer sempre menor que o pai. A vida-em-fracasso de Karl Rossmann se deve, em grande parte, à alienação do personagem, que não percebe que todo microespaço por onde passa tem a sua própria lei, consequentemente, a sua própria justiça, a sua própria forma de sentenciar e o seu próprio regime democrático. De fato, Karl não consegue fazer pactos com essas leis, pois essas leis não correspondem à sua ideia de lei: “Os protagonistas de Kafka são elementos perturbadores [...] não sabem pactuar e entrar em compromisso, por mais que o queiram" (ROSENFELD, 2015, p. 227).

Por não firmar pactos, Karl é expulso de quase todos os microespaços por onde transita, exceção feita ao microespaço do 
Theatro de Oklahama, que se organiza como uma comunidade: "Por comum, é preciso entender, ao mesmo tempo, o banal, ou seja, o elemento de uma igualdade primordial e irredutível a todo efeito de distinção, e - indiscernivelmente - o partilhado, ou seja, o que somente tem lugar na relação, por ela e como ela: consequentemente, o que não se define nem em 'ser' nem em 'unidade'" (NANCY, 2014, p. 11-2). No Theatro, caso excepcional em Kafka, todas as diferenças são aceitas e neutralizadas, uma vez que todos estão de acordo com a função definida a cada um segundo as suas aptidões: "Como já viram no nosso cartaz, podemos aproveitar a todos. É claro que precisamos saber que profissão cada um exerceu até agora, para que possamos empregá-lo no lugar certo, onde ele possa aplicar seus conhecimentos" (KAFKA, 2012, p. 255). Neutraliza-se o indivíduo transferindo a sua vontade de poder para a vontade de poder da própria comunidade do Theatro. O ser central é a comunidade, não o indivíduo, até porque "o indivíduo é apenas o resíduo da prova da dissolução da comunidade" (NANCY, 2004, p. 16). Se há comunidade - não confundir com sociedade - não há indivíduo. Dessa forma, o Theatro de Oklahama pode ser compreendido também como uma representação da boa democracia, no qual os seres partilham de fato de um sistema em que todos são iguais perante a lei, a lei da comunidade: "A 'igualdade de condições', efetivamente, é a dissociação do ter mais e do ser mais" (RANCIÈRE, 2017, p. 235).

Com o Theatro de Oklahama, já no final de $O$ desaparecido, poderíamos pensar em uma certa redenção de Karl ou uma chance, depois de tantos revezes, de ele poder confirmar a existência da boa democracia americana: "Para Karl, porém, havia um grande atrativo no cartaz: 'Todos são bem-vindos', era o que constava. Todos, portanto também Karl" (KAFKA, 2012, p. 248). Entretanto, o tempo de vida da boa democracia é abreviado pelo tempo de vida da má democracia, que, graças ao seu regime por vezes opressor, porém, também libertário, coíbe a expansão de um sistema comunitário que pode originar um sistema mais opressor do que a própria má democracia, pois a homogeneidade tende a eliminar toda diferença, toda forma de pensar e de agir diferente. E assim, se torna autoritária, abusiva e destrutiva, exemplos não faltam em nossa História humana, como o nazismo, o fascismo e outros sistemas obscuros da 
humanidade que tiveram como ponto de partida uma ideia feliz de comunidade que acabou por originar um sistema de supressão do humano enquanto diferença. Nessa perspectiva, a má democracia, com toda a sua instabilidade e complexidade, se torna mais democrática do que a boa democracia, uma vez que permite a irrupção da alteridade. E isso Kafka sabia e sobre isso escreveu, daí a crítica à utopia democrática americana que podemos extrair da leitura de $O$ desaparecido ou Amerika. Embora carregado nas tintas no final de sua narrativa, com um possível final feliz digno dos melhores blockbusters americanos, O desaparecido não é exceção no todo da obra kafkiana: "É um mistério que $O$ desaparecido consiga emanar tal sensação de felicidade e, ao mesmo tempo, um desespero tão agudo. Uma combinação desconcertante, que não se encontra em outro lugar" (CALASSO, 2006, p. 170). Kafka, diferente de um Deus que vacila, arremessa seus personagens à realidade da vida: à morte, ao fracasso, à desilusão... à má democracia.

Apesar de o romance $O$ desaparecido estar inacabado, como $O$ castelo e $O$ processo, e não nos permitir textualmente afirmar o fracasso que se apresentará logo após a incursão de Karl no Theatro, o inventário de sua vida cíclica não nos deixa mentir: Karl estudante (esperança); Joanna Brummer e a violação (fracasso); América e o Tio Jakob (esperança); desobediência involuntária em relação ao tio e a expulsão de sua casa (fracasso); caminhada com Robinson e Delamarche à procura de emprego (fracasso); emprego no Hotel occidental e Grete Mitzelbach, a cozinheira-mor (esperança); falta involuntária no Hotel occidental (fracasso); Grete Mitzelbach e o cartão de visitas com sua recomendação para a Pensão Brenner (esperança); revista do porteiro-mor e a perda do cartão de visitas da cozinheira-mor (fracasso); fuga do policial (fracasso); salvo por Delamarche (esperança); preso como criado no apartamento de Delamarche e Brunelda (fracasso); fuga com Brunelda (esperança); Theatro de Oklahama (esperança). Talvez as reticências no final do romance comprovem, mais até do que o ponto final, que o movimento da vida é cíclico, e não estagnado, e que o fracasso faz parte da vida de Karl, ou melhor, faz parte da vida de todos nós, assim como a esperança. E essa alternância, que possibilita a vida, somente pode existir em um sistema que preze a diferença, não a semelhança: 
Efetivamente, é isso que está no âmago da democracia, da "má" democracia: a fronteira instável, perpetuamente contestada e perpetuamente cruzada, às vezes erguida em barricada, a fronteira onde se definem as relações entre ver e não ver, ser visto ou não ser visto, ser visível e ser dizível; a fronteira onde o anônimo dá a si mesmo um nome que é o de alguma comunidade, onde o qualquer dá a si mesmo uma forma que é a da multidão, mas também, ao contrário, o lugar onde aquilo que estava reunido se dispersa novamente, condenando à mentira o que era verdade, onde a promessa desfeita corre o risco de se transformar em ódio que reúne. (RANCIÈRE, 2017, p. 238)

\section{2. еи maior quе теи раi}

Apenas uma narrativa kafkiana pode ser vista sob o prisma do eu maior que meu pai: Carta ao pai. Longe de parecer somente uma escrita-testamento real sobre a lei despótica de um pai e as suas consequências traumáticas na vida de um filho, Kafka faz de sua carta um teatro farsesco ou, se preferirmos, um teatro de máscaras, no qual Kafka representa o papel do filho humilhado e o pai o papel do carrasco: "Você assumia para mim o que há de enigmático em todos os tiranos, cujo direito está fundado, não no pensamento, mas na própria pessoa" (KAFKA, 1997, p. 15-6). Antes de ser testemunho, Carta ao pai é uma narrativa ficcional: "A famosa Carta ao pai deve ser lida, em ampla medida, como ficção, embora naturalmente contenha um fundo autobiográfico" (ROSENFELD, 2015, p. 254). E como nos lembra Derrida, em Demeure, todo testemunho tem a sua parcela de ficção: "Como promessa de fazer a verdade, segundo a expressão de Agostinho, ali onde a testemunha deve ser a única, insubstituível, ali onde ela é a única a poder morrer sua própria morte, o testemunho sempre está em parte ligado à possibilidade ao menos da ficção, do perjúrio e da mentira" (DERRIDA, 1998, p. 28). Seguindo essa perspectiva, Carta ao pai, tendo como base a sua própria estrutura significativa, passa a questionar o montante de leituras de cunho edipiano que forçosamente a limita. É certo que Kafka, ou o personagem Kafka, acusa de modo direto e indireto o pai, mas nunca de baixo para cima, como poderia sugerir um ser complexado, mas de cima para baixo. O ser que humilha, agora, é o filho, não o 
pai. Na luta de poderes de um sistema democrático possível, o filho vence de modo incontestável:

Estou convencido de que casar, fundar uma família, acolher todos os filhos que vierem, mantê-los neste mundo inseguro e guiá-los um pouco, é o máximo que um homem pode em geral conseguir. $\mathrm{O}$ fato de serem tantos os que o conseguem não é uma prova em contrário, pois em primeiro lugar efetivamente não são muitos os que conseguem, e em segundo esses poucos não o "fazem", simplesmente "acontece" com eles [...] (KAFKA, 1997, p. 59).

O poder do filho se concentra na palavra: qualquer um pode se tornar pai, mas nem todos são pais. Kafka conhece os recursos da língua alemã e sabe se aproveitar disso para ironizar, diminuir, menosprezar, sucatear, desconstruir e ridicularizar a lei paterna: "Não era permitido partir os ossos com os dentes, mas você podia. [...] Ầ mesa não era permitido se ocupar de outra coisa a não ser da refeição, mas você polia e cortava as unhas, apontava lápis, limpava os ouvidos com o palito de dentes" (KAFKA, 1997, p. 19). A animalidade paterna é confrontada continuamente pelo uso esmerado das palavras escolhidas sob medida pelo filho-humilhado: "Você só pode tratar um filho como você mesmo foi criado, com energia, ruído e cólera, e neste caso isso lhe parecia, além do mais, muito adequado, porque queria fazer de mim um jovem forte e corajoso" (KAFKA, 1997, p. 12). Em seu levantamento das faltas paternas, o pai é diminuído a todo momento, sobretudo quando o filho diz ser ameaçado por sua estrutura corpórea intimidadora, pois sabe que agora ela nada pode contra a sua força-de-escrita: “Já estava esmagado pela simples materialidade do seu corpo" (KAFKA, 1997, 14). A todo instante, Kafka parece rir e, assim, os papéis de carrasco e de vítima se invertem, se multiplicam e se espelham. Ao fim de Carta ao pai, nos perguntamos: quem é o algoz e quem é a vítima? Pois não se deixem confundir quando Kafka diz "não quero dizer que", uma fórmula que exime o pai de qualquer culpa, pois essa fórmula esconde sempre um "quero dizer que", que acusa e castiga o pai por tudo de ruim que aconteceu e que acontece em sua vida: “Esse deslizamento perverso, que extrai da inocência suposta do pai uma acusação ainda pior, tem, evidentemente, uma meta, um efeito e um procedimento" (DELEUZE; GUATTARI, 2015, p. 22). 
Um efeito de degradação paterna que distancia cada vez mais uma leitura de natureza edipiana: "Pela última vez, psicologia!" (KAFKA, 2011, p. 204). Segundo Freud, o complexo de Édipo se constrói a partir de uma tríade, ou seja, a partir de três elementos: um primeiro elemento sentiria desejo pelo segundo, sendo que o segundo já teria estabelecido um vínculo com o terceiro, tendo o terceiro, ou mesmo o segundo, que punir o desejo do primeiro. Na maioria dos casos relatados, os três elementos são compostos por mãe, pai e filho(a). Em se tratando de Kafka, a figura da mãe é quase inexistente, como em $O$ desaparecido, ou não passa de um simples elemento que não pode confrontar o pai, uma vez que não tem o poder para enfrentá-lo, como em Carta ao pai. Nas setenta e quatro páginas da carta kafkiana, a figura da mãe aparece somente em nove delas, sempre de modo protetor, acolhedor, bajulador, mas também sempre de modo faltoso, apático e sem vida própria, sendo sucessivamente apagada pela presença do marido. A mãe é de uma fragilidade semelhante à do filho: "minha mãe me protegia de você às escondidas e me dava alguma coisa, me permitia algo em segredo" (KAFKA, 1997, p. 29). E já que estamos empreendendo um rápido levantamento da teoria edipiana, não podemos esquecer que em Carta ao pai está descartada toda e qualquer extensão de um desejo sexual do filho pela mãe ou do filho pelo pai.

No primeiro caso, a mãe não fomenta qualquer sensação para além do espaço materno protetor faltoso. No segundo caso, por mais que houvesse o desejo do filho pelo pai, não haveria o corte efetuado pela mãe, pelo terceiro elemento, pois a mãe não teria força suficiente para ser o contraponto de uma força paterna tão grande. Mas o pai, como a mãe no primeiro caso, não fomenta no filho nenhum apelo sexual, nem mesmo nenhuma extensão possível de um desejo sexual, muito menos um certo viver junto: o espaço literário no qual o filho habita exclui o espaço real no qual o pai estabelece o seu domínio. A literatura é o grande poder ao qual Kafka, o filho, está submetido pelo desejo.

Blanchot, em "Kafka e a exigência da obra", nos apresenta um trecho do Diário Íntimo de Kafka que ilustra de modo significativo o seu desejo pela literatura: “'Quando o meu organismo se deu conta de que escrever era a direção mais fecunda do meu ser, tudo para aí se dirigiu e foram 
abandonadas todas as outras capacidades, aquelas que têm por objetivo os prazeres do sexo, da bebida, da comida, da meditação filosófica e, sobretudo, da música'" (BLANCHOT, 1987, p. 59). Se nos basearmos na teoria freudiana, a tríade que estrutura o complexo de Édipo não existe na narrativa de Carta ao pai: "O complexo de Édipo ofereceu ao menino duas possibilidades de satisfação, uma ativa e uma passiva. Ele pôde, masculinamente, colocar-se no lugar do pai e tal como este relacionar-se com a mãe, caso em que o pai logo foi visto como empecilho, ou quis substituir a mãe e se fazer amar pelo pai, caso em que a mãe se torna supérflua" (FREUD, 2011, p. 208).

De modo algum o menino Kafka se colocou no lugar do pai ou da mãe: "Lícito seria esperar que a soberana visão que Kafka teve da psicanálise contribuísse para apartar pelo menos a ele mesmo de tal âmbito restritivo" (CANETTI, 1988, p. 93). Kafka presta contas, sim, ao pai, mas de forma a mantêlo à distância e irrevogavelmente inferior a partir de uma realidade deformada, criada, amplificada e desterritorializada: “Desterritorializar Édipo no mundo, em lugar de se reterritorializar sobre Édipo e na família. Mas, para isso, era preciso ampliar Édipo ao absurdo, até o cômico, escrever a Carta ao pai. [...] 'A revolta contra o pai é uma comédia, não uma tragédia'”' (DELEUZE; GUATTARI, 2015, p. 24).

\section{3. eu igual aо теи pai}

Dois elementos de forças contrárias, semelhantes a Caim e Abel, não podem habitar o mesmo espaço sem que um tente matar o outro, sem que um tente submeter o outra à sua força, ao seu poder. Nos escritos de Kafka, não há nenhum precedente que possa ser enquadrado no eu igual ao meu pai:

A igualdade que então surgiria entre nós, e que você poderia compreender como nenhuma outra, eu a imagino tão bela porque então seria um filho livre, grato, sem culpa, sincero, e você um pai sem angústia, não despótico, compreensivo, satisfeito. Mas para chegar a esse objetivo, tudo o que aconteceu teria de ser desfeito, isto é: nós mesmos teríamos de ser apagados. (KAFKA, 1997, p. 67-8)

Apagar a si e o pai, o presente e o passado, é de todo impossível. 


\section{Epílogo}

Kafka, enquanto fabulador realista, como o nomeia Günther Anders, em Kafka: pró e contra, enquanto escritor que desterritorializa a língua alemã sem abrir mão de sua sobriedade linguística, elevando-a, ao mesmo tempo, a um patamar poético-performático, apresenta-nos em sua ficção, a partir do sistema opressor no qual se enquadram pais e filhos, uma democracia social e, sobretudo, familiar que dialoga fortemente com a nossa democracia real. Kafka, enquanto escritor sensível de seu tempo, compreendeu desde muito cedo que a boa democracia não poderia dar bons frutos, ela homogeneíza, e que a má, ainda que injusta ou opressora, continua sendo o meio pelo qual a liberdade pode se fazer presente, com indivíduos exercendo a sua diferença, cabendo a nós superar a vontade de poder que exclui muitos e elege poucos. Na verdade, a boa democracia seria aquela em que todo homem poderia ter direito à voz. Esse ter voz é a grande dificuldade dos indivíduos kafkianos, que têm as suas vozes abafadas por um pai/sistema autoritário que não os deixa falar e, quando falam, não são ouvidos nem compreendidos. Karl não pôde falar sobre a sua violação, Gregor não foi compreendido por seus familiares e Georg teve a sua voz anulada por seu pai, restando-lhe a morte. Em Kafka, não ter voz é o mesmo que morrer. E os que têm voz são opressores, tiranos, déspotas - qualquer semelhança com a nossa realidade não seria mera coincidência, uma vez que estamos falando de Kafka, um fabulador realista: "E com isso ascendo às regiões das montanhas geladas e me perco para nunca mais" (KAFKA, 2011, p. 131).

\section{REFERÊNCIAS}

ADORNO, T. W. Prismas: crítica cultural e sociedade. Tradução de Augustin Wernet e Jorge Mattos Brito de Almeida. São Paulo: Ática, 1998.

ANDERS, G. Kafka: pró e contra. Tradução de Modesto Carone. São Paulo: Cosac Naify, 2007.

BENJAMIN, W. Magia e técnica, arte e política. Tradução de Sérgio Paulo Rouanet. São Paulo: Brasiliense, 2012 (Tomo I das Obras Escolhidas). 
BLANCHOT, M. O espaço literário. Tradução de Álvaro Cabral. Rio de Janeiro: Rocco, 1987.

CALASSO, R. K. Tradução de Samuel Titan Jr. São Paulo: Companhia das Letras, 2006.

CANETTI, E. O outro processo. Tradução de Herbert Caro. Rio de Janeiro: Espaço e Tempo, 1988.

CARONE, M. Lição de Kafka. São Paulo: Companhia das Letras, 2009.

DELEUZE, G.; GUATTARI, F. Mil platôs: capitalismo e esquizofrenia 2, v. 1. Tradução de Ana Lúcia de Oliveira, Aurélio Guerra Neto e Célia Pinto Costa. São Paulo: Editora 34, 2011.

. Kafka: por uma literatura menor. Tradução de Cíntia Vieira da Silva. Belo Horizonte: Autêntica, 2015.

DERRIDA, J. Préjugés: devant la loi. In: LYOTARD, J.-F (Org.) et al. La faculté de juger. Paris: Minuit, 1985. p. 87-139. . De l'hospitalité. Paris: Calmann-Lévy, 1997. . Demeure: Maurice Blanchot. Paris: Galilée, 1998.

FREUD, S. Obras Completas, v. 16: O eu e o id, "autobiografia" e outros textos (1923-1925). Tradução de Paulo César de Souza. São Paulo: Companhia das Letras, 2011.

HUXLEY, A. Admirável mundo novo. Tradução de Lino Vallandro e Vidal Serrano. São Paulo: Globo, 2014.

KAFKA, F. Carta ao pai. Tradução de Modesto Carone. São Paulo: Companhia das Letras, 1997.

A metamorfose. Tradução de Modesto Carone. São Paulo: Companhia das Letras, 1997a.

. O veredicto/Na colônia penal. Tradução de Modesto Carone. São Paulo: Companhia das Letras, 1998.

Essencial Franz Kafka. Tradução de Modesto Carone.

São Paulo: Penguin Classics / Companhia das Letras, 2011. 
KAFKA, F. O desaparecido ou Amerika. Tradução de Susana Kampff Lages. São Paulo: Editora 34, 2012.

NANCY, J-L. La Communauté déscuvrée. Paris: Christian Bourgois, 2004.

. La Communauté désavouée. Paris: Galilée, 2014.

RANCIÈRE, J. Políticas da escrita. Tradução de Raquel Ramalhete, Laís Eleonora Vilanova, Lígia Vassalo e Eloisa Araújo Ribeiro. São Paulo: Editora 34, 2017.

ROSENFELD, A. Letras e leituras. São Paulo: Perspectiva, 1994. . Texto/Contexto I. São Paulo: Perspectiva, 2015. 


\section{Abstract \\ Amerika by Franz Kafka: from father to son}

This article analyzes the novel Amerika: the missing person, by Franz Kafka, the configuration of paternal law as an oppressive system that judges and sentences the son according to a predefined concept law, which turns this judgment into a fiction. Two democratic territories, a utopian and a real one, that are presented as a scenery of the judgment, as also as, the punishment of the son. In the face of father's law, the son has no possibilities of choice, because he is already entangled in the original sin that has sentenced him as guilty before his own existence. In the development of this article, three narratives of Kafka are presented like exercises of reflection about this autocratic paternal law such as: The metamorphosis, The judgement and Letter to my father. Texts from Jacques Derrida, "Préjugés: devant la loi" and from Jacques Rancière, "O continente democrático", which give this article a theorical framework from which Kafka's paternal law can be thought.

Keywords: Franz Kafka, Jacques Derrida, Jacques Ranciére, Paternal law, democracy. 